\title{
A NEW SECTIONAL NAME FOR THE BRAZILIAN TETRAPLOID CLADE OF DROSERA SUBGENUS DROSERA
}

\author{
AndReas FleischmanN • Botanische Staatssammlung München • Menzinger Strasse 67 • D-80638 \\ Munich・Germany・fleischmann@1rz.uni-muenchen.de \\ Paulo Minatel Gonella • R. Cid Silva Cesar, 1039 • São Carlos • SP • 13562-400 • Brazil \\ -paulogonella@uol.com.br \\ FERNANDO RIVADAVIA •185 SW 7th St•Miami・Florida 33130・USA・fe_riva@uol.com.br
}

Keywords: taxonomy, Drosera sect. Brasiliae, classification, phylogeny.

Historical infrageneric classifications of the genus Drosera L. (De Candolle 1824; Planchon 1848a, b; Diels 1906; Seine \& Barthlott 1994; Schlauer 1996) took into account the external morphology of its species, especially style division, but also data from palynology (Takahashi \& Sohma 1982), trichome morphology (Seine \& Barthlott 1993; Länger et al. 1995) and chromosome numbers (e.g., Kondo 1976). Nevertheless, when confronted with the molecular phylogenetic reconstructions (Rivadavia et al. 2003, 2012), all existing classifications were unsuccessful in circumscribing a monophyletic $D$. section Drosera, due to the high homoplasy of morphological traits in that section. Hence, a new classification congruent with the phylogeny and based on monophyletic groups became necessary (Fleischmann et al. 2018).

The phylogenetic reconstructions of Rivadavia et al. $(2003,2012)$, based on the plastid marker $r b c L$, showed that all Drosera species, except for D. regia Stephens and D. arcturi Hook., belong to two large sister clades more or less geographically defined, an "Australian Clade" (D. subgen Ergaleium, comprising D. sections Coelophylla, Lasiocephala, Bryastrum, Erythrorhiza, Stolonifera and Ergaleium), and another clade representing an "out of Australia" movement. The latter has to be referred to as $D$. subgen. Drosera (as it contains the generic type, D. rotundifolia L.), with clades connected to basal nodes centered in Australia (D. sections Arachnopus, Stelogyne, Prolifera, Psychophila, Thelocalyx), and clades connected to more apical nodes of Neotropical and African distribution $(D$. sections Ptycnostigma, and Drosera sensu Seine \& Barthlott 1994). In this topology, D. sect. Drosera (sensu Seine \& Barthlott 1994) appears as paraphyletic with D. sect. Ptycnostigma nested within.

To better reflect the phylogenetic, geographical, and morphological groups, we adopted the topology of Rivadavia et al. (2012) for a new classification of the taxa hitherto placed in $D$. sect. Drosera. Therefore, $D$. sect. Drosera is here redefined as the clade containing D. rotundifolia (the type species of the genus), along with other temperate and diploid Neotropical taxa, as well as $D$. spatulata Labill and allied taxa. This clade is sister to two clades, the "African clade" (which contains D. sect. Ptycnostigma) and the "Brazilian Tetraploid clade" (Rivadavia et al. 2003, 2012; Gonella 2012). Consequently, D. sect. Ptycnostigma (whose type is D. pauciflora Banks ex DC.) is here expanded to include all taxa that fall within the "African clade". Finally, the "Brazilian Tetraploid clade" remains unnamed, and a new sectional name is here proposed.

\section{Drosera section Brasiliae Rivadavia, Gonella \& A.Fleischm., sect. nov.}

Type: Drosera graminifolia A.St.-Hil., Hist. Pl. Remarq. Bresil 1(7): 269, t. 25C (1828).

This section comprises the species of the "Brazilian Tetraploid clade", a monophyletic group that emerged in the phylogenetic reconstructions of Rivadavia et al. (2003, 2012). The sectional name 
refers to the predominantly Brazilian distribution and the likely Brazilian origin of this evolutionary lineage.

Of the 18 species belonging to this section (Table 1), chromosome numbers are known for nine, which are consistently $2 n$ $=40$ (Futagawa et al. 2002; Rivadavia et al. 2003; Rivadavia 2005). The species are also recognized by morphological characters such as an indumentum of translucentyellow, short-stalked globose non-carnivorous trichomes in most species (Fig. 1; Gonella 2012; Gonella et al. 2014; Rivadavia et al. 2014; however, they are not an apomorphy for this section, these glands are also found in other species, e.g. D. meristocaulis Maguire \& Wurdack, see Rivadavia et al. 2012), scapes often covered by a woolly indumentum of long, patent eglandular hairs and, most notably, circinate leaf vernation (Fig. 2; all except D. tentaculata, which is uniquely simple-geniculate among Brazilian sundews; Rivadavia et al. 2014). All sympatric members of other sections display geniculate-involute vernation (D. sects. Bryastrum and Drosera) or entire-involute vernation $(D$. sect. The-

Table 1. Species included in Drosera sect. Brasiliae.

\begin{tabular}{|l|l|}
\hline$\#$ & \multicolumn{1}{|c|}{ Species } \\
\hline 1 & D. ascendens A.St.-Hil. \\
\hline 2 & D. camporupestris Rivadavia \\
\hline 3 & D. chimaera Gonella \& Rivadavia \\
\hline 4 & D. chrysolepis Taub. (Front Cover) \\
\hline 5 & D. graminifolia A.St.-Hil. \\
\hline 6 & D. grantsaui Rivadavia \\
\hline 7 & D. graomogolensis T.R.S.Silva \\
\hline 8 & D. latifolia (Eichl.) Gonella \& Rivadavia \\
\hline 9 & D. magnifica Rivadavia \& Gonella \\
\hline 10 & D. montana A.St.-Hil. \\
\hline 11 & D. quartzicola Rivadavia \& Gonella \\
\hline 12 & D. riparia Rivadavia \& Gonella \\
\hline 13 & D. schwackei (Diels) Rivadavia \\
\hline 14 & D. spiralis A.St.-Hil. \\
\hline 15 & D. spirocalyx Rivadavia \& Gonella \\
\hline 16 & D. tentaculata Rivadavia \\
\hline 17 & D. tomentosa A.St.-Hil. \\
\hline 18 & D. villosa A.St.-Hil. \\
\hline
\end{tabular}
localyx) (Gonella 2012; Rivadavia et al. 2014).

Circinate leaf vernation is homoplastic in Drosera, as this characteristic appears independently in several lineages, including in three members of $D$. sect. Drosera (see below), and may be generally connected to more elongated leaf and lamina shapes (this is paralleled in the unrelated genus Pinguicula L. of Lamiales, where species with filiform leaves show circinate vernation). Such characteristic is also present in the three Andean species revised by Gonella et al. (2016), however, due to the unique combination of characters and the fact that these taxa were not sampled in any published molecular phylogenetic studies so far, these species remain unplaced for now.

\section{Drosera section Drosera}

Type: Drosera rotundifolia L.

三Drosera section Rossolis Planch., Ann. Sci. Nat., Bot., sér. 3(9): 92 (1824). nom. superfl.

EDrosera section Eurossolis Diels, Pflanzenr. 26: 62 (1906). nom. superfl.

=Drosera section Oosperma Schlauer, Carniv. Pl. Newslett. 25: 70 (1996).

Type: Drosera intermedia Hayne

Drosera sect. Drosera, as here redefined, includes all taxa belonging to the clade containing $D$. rotundifolia in the phylogeny of Rivadavia et al. (2012). Species of this section present chromo- 


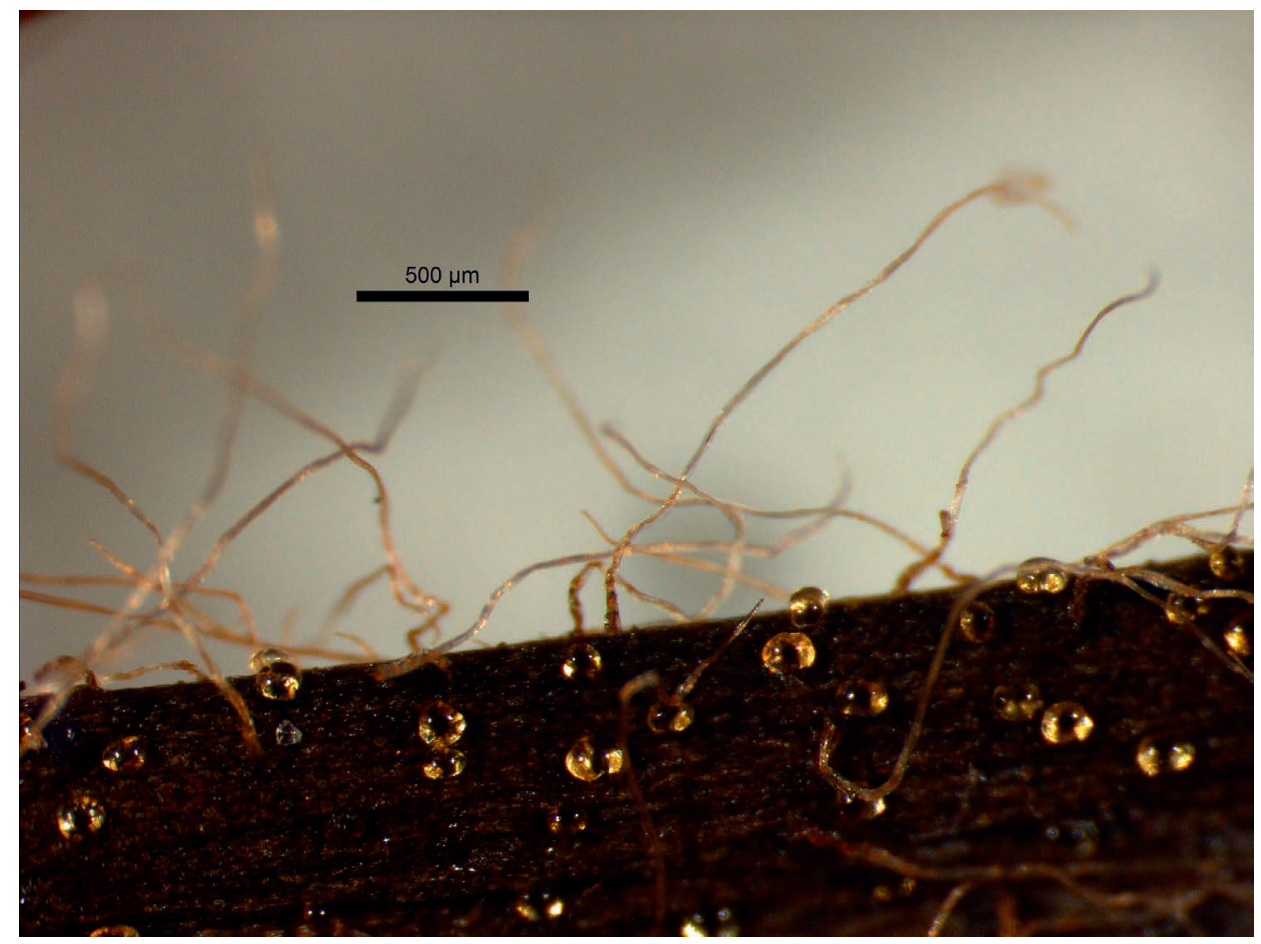

Figure 1: Indumentum of translucent-yellow, short-stalked globose non-carnivorous trichomes and eglandular hairs of the petiole of a herbarium specimen of Drosera graminifolia, the type species of $D$. sect. Brasiliae. Photo: Paulo M. Gonella.

some numbers of $2 n=20$ (except for $D$. anglica Huds., a species of amphiploid hybrid origin, with $2 n=40$; Rivadavia et al. 2003, and perhaps a few taxa of recent genome duplication). The species of the section are also characterized by spatulate leaves with geniculate-involute leaf vernation or, more rarely, circinate vernation in the species with linear leaves (D. filiformis Raf., D. tracyi (Diels) Macfarl. and D. linearis Goldie).

Drosera section Oosperma Schlauer (1996), was segregated from D. sect. Drosera based on the ovoid seed shape (vs. fusiform) and has as type-species D. intermedia Hayne. According to the topology found in the phylogenetic reconstruction of Rivadavia et al. (2012), ovoid seed shape is homoplastic, and taxa that would be classified as belonging to $D$. sect. Oosperma based on the section description provided by Schlauer (1996), can be found spread in D. sections Drosera, Brasiliae and Ptycnostigma. Hence, Drosera section Oosperma as circumscribed by Rivadavia (2003) is polyphyletic, as it additionally included four of the tetraploid Brazilian taxa, which belong to a different clade herewith classified as D. section Brasiliae. As the type of D. section Oosperma, D. intermedia, is part of the clade that is also comprising the generic type, D. rotundifolia (and hence the type of $D$. sect. Drosera), $D$. section Oosperma (sensu Schlauer 1996) is here placed under synonymy of $D$. sect. Drosera.

Drosera sect. Brasiliae is sister to a more widely circumscribed D. sect. Ptycnostigma, i.e. the clade comprising D. pauciflora and all other African sundews except D. regia and D. indica (Fleischmann et al. 2018): 


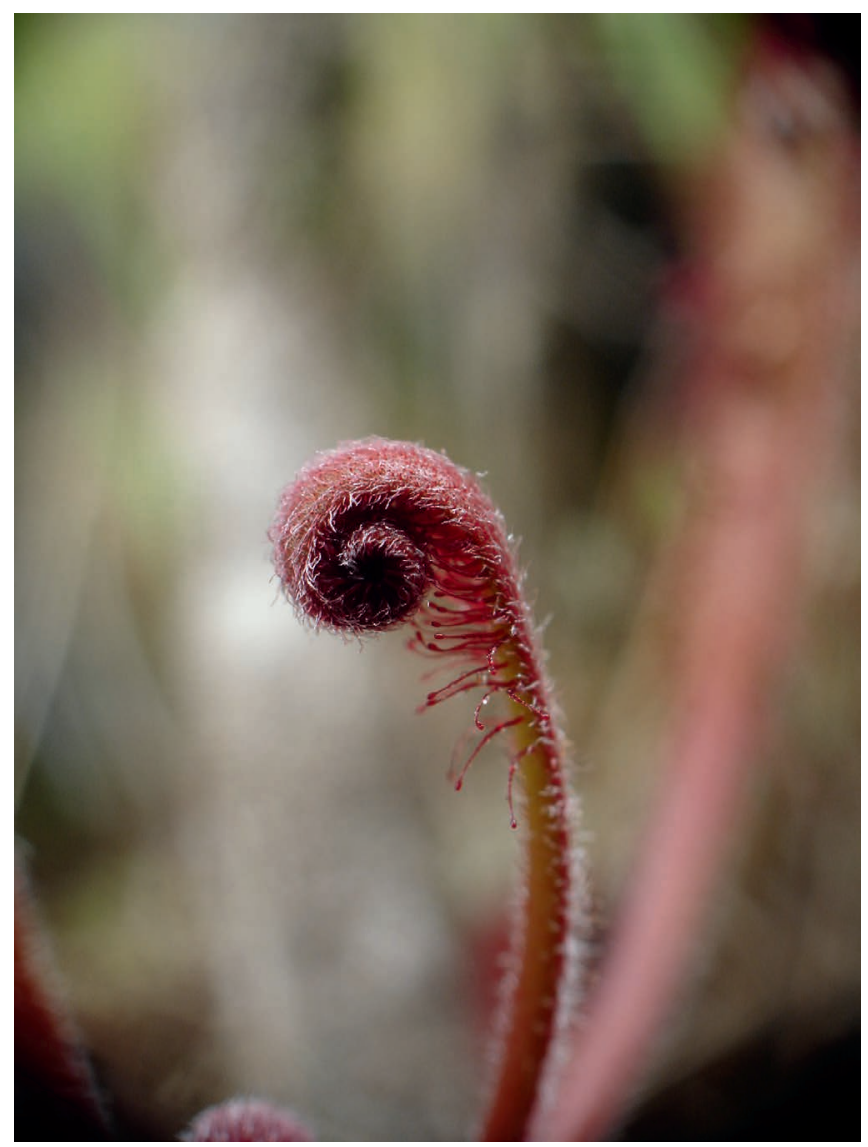

Figure 2: Circinate leaf vernation of Drosera villosa: the leaf in bud of most members of $D$. sect. Brasiliae is enrolled like a mainspring or crozier - which distinguishes this affinity from other Neotropical Drosera. Photo: Paulo M. Gonella.

Drosera section Ptycnostigma Planchon, Ann. Sci. Nat., Bot., sér. 3(9): 92-93 (1848).

Type: Drosera pauciflora Banks ex DC., Prodr. 1: 317 (1824).

=Drosera section Crypterisma Planchon, Ann. Sci. Nat., Bot., sér. 3(9): 92 (1824).

Type: Drosera hilaris Cham. \& Schltdl.

=Drosera section Vagae Drude, Nat. Pflanzenfam. 3(2): 271 (1891).

Type: Drosera capensis L.

This section, as here redefined, includes all species belonging to the "African clade" in the phylogeny of Rivadavia et al. (2012), which comprises all Drosera species occurring on the African continent, with the exception of $D$. regia (D. subgen. Regiae) and $D$. indica L. $(D$. sect. Arachnopus). Regarding chromosome number, this section is quite heterogeneous, with variable numbers $(2 n=20,40,60$ or 80 ; Rivadavia et al. 2003). Most common leaf vernation pattern is geniculate-involute, but circinate is also present in some taxa (D. pauciflora, D. alba E.Phillips, and allied taxa). 
In the original circumscription, Planchon $(1848 \mathrm{a}, \mathrm{b})$ defined $D$. sect. Ptycnostigma as plants with flowers with multi-flabellate stigmata, succulent roots, and lacking stipules, containing only D. cistiflora L. and D. pauciflora. In the current expanded circumscription, all these three traits are not present in all taxa.

The summer-dormant, South African species with succulent roots (D. cistiflora, D. pauciflora, and allied taxa), which were segregated in D. sect. Ptycnostigma by Planchon (1848a, b; elevated to subgeneric rank by Diels 1906 and adopted by Schlauer 1996) are nested within a clade of African Drosera species (belonging to D. section Drosera sensu Diels 1906). The discrete classification of the summer-dormant species was reasoned by Planchon (1848a) based on the distinctive multifid-flabellate stigmata, a concept followed by Diels (1906), who even gave further weight to the stigma shape in his $D$. subgenus Ptycnostigma. However, this proved to be inconsistent, as the doubtlessly related $D$. trinervia (summer-dormant, stipules reduced) was not included in this affinity, but treated by Diels (1906) and subsequent authors in $D$. subgen. Drosera. Moreover, a grade of morphological characters connects the summer-dormant species of $D$. subgen. Ptycnostigma with the perennially growing species of $D$. subgen. Drosera (sensu Diels 1906). A clear example is the stipule reduction observed in D. hilaris, which connects to the stipule-lacking summer-dormant species circumscribed by Diels in his D. subgen. Ptycnostigma. Drosera hilaris was even placed in its own section, Crypterisma, by Planchon (1848a, b; spelled "Cripterisma" in the former source), based on its peculiar morphology. However, it is morphologically connected to the other South African Drosera species - both the perennially growing and the summer-dormant, hemicryptophyte species, to the former by overall flower morphology and to the latter by absence of stipules (Fleischmann et al. 2018). Further support is gained from molecular phylogenetic data, which show $D$. hilaris nested within a clade of South African Drosera species (Rivadavia et al. 2003), including those of Ptycnostigma (sensu Diels 1906).

Additionally, a similar type of non-carnivorous glandular trichomes was observed in all African Drosera species (except $D$. regia and D. indica) by Länger et al. (1995). Thus Seine \& Barthlott (1994) correctly merged Planchon's section/Diels' subgenus Ptycnostigma with D. subgenus Drosera. However, as D. section Drosera proved to be paraphyletic (Rivadavia et al. 2003; Fleischmann et al. 2018), and as the clade comprising the African members does not contain the generic type, $D$. rotundifolia, Planchon's sectional name Ptycnostigma is here re-elevated in a larger circumscription to classify all Drosera species of the African clade (viz. all species of Drosera that occur in Africa, excluding $D$. indica and $D$. regia).

The stigma shape of the summer-dormant species D. cistiflora, D. pauciflora, and allies is not a reliable taxonomic character for infrageneric classification, and rather seems to mirror adaptations to certain pollinator groups in these large-flowered species. The doubtlessly closely related $D$. trinervia (support comes from life strategy, morphology, and molecular data) does not share flabellate stigmata, but has simple spatulate-bifid stigmatic apices; in contrast, the only distantly related $D$. regia of $D$. subgenus Regiae also flabellate stigmata with multiple divisions.

\section{References}

De Candolle, A.P. 1824. Droseraceae. Prodomus systematis naturalis regni vegetabilis 1: 317-320. Diels, L. 1906. Droseraceae. In: Engler, H.G.A. (ed). Das Pflanzenreich 26,4: 1-136.

Fleischmann, A., Cross, A.T., Gibson, R., Gonella, P.M., and Dixon, K.W. 2018. Systematics and evolution of Droseraceae. In: Ellison, A.M. \& Adamec, L. (eds.): Carnivorous Plants: physiology, ecology, and evolution. Oxford University Press: 45-57. 
Futagawa, K., Suzuki, R., and Kondo, K. 2002. A molecular cytogenetic study in Drosera filiformis and D. graminifolia. Proceedings of the 4th ICPS Conference, Tokyo, Japan: 131-140.

Gonella, P.M. 2012. Revisão taxonômica do clado tetraploide-brasileiro de Drosera L. (Droseraceae). Master thesis, Universidade de São Paulo. 222 pp.

Gonella, P.M., Rivadavia, F., Sano, P.T., and Fleischmann, A. 2014. Exhuming Saint-Hilaire: revision of the Drosera villosa complex (Droseraceae) supports 200 year-old neglected species concepts. Phytotaxa 156: 1-40.

Gonella, P.M., Fleischmann, A., Rivadavia, F., Neill, D.A., and Sano, P.T. 2016. A revision of Drosera (Droseraceae) from the central and northern Andes, including a new species from the Cordillera del Condor (Peru and Ecuador). Plant Systematics and Evolution 302: 1419-1432.

Kondo, K. 1976. A cytotaxonomic study in some species of Drosera. Rhodora 78: 532-541.

Länger, R., Pein, I., and Kopp, B. 1995. Glandular hairs in the genus Drosera (Droseraceae). Plant Systematics and Evolution 194: 163-172.

Planchon, J.E. 1848a. Sur la famille des Droséracées. Annales des Sciences Naturelles, Botanique, Série 3, 9: 79-99.

Planchon, J.E. 1848b. Sur la famille des Droséracées. Revisio Systematica Droseracearum. Annales des Sciences Naturelles, Botanique, Série 3, 9: 185-207.

Rivadavia, F. 2003. Four new species of sundews, Drosera (Droseraceae), from Brazil. Carnivorous Plant Newsletter 32: 79-92.

Rivadavia, F. 2005. New chromosome numbers for Drosera L. (Droseraceae). Carnivorous Plant Newsletter 34: 85-91.

Rivadavia, F., Kondo, K., Kato, M., and Hasebe, M. 2003. Phylogeny of the sundews, Drosera (Droseraceae), based on chloroplast $r b c L$ and nuclear $18 \mathrm{~S}$ ribosomal DNA Sequences. American Journal of Botany 90: 123-130.

Rivadavia, F., Miranda, V.F.O., Hoogenstrijd, G., Pinheiro, F., Heubl, G., and Fleischmann, A. 2012. Is Drosera meristocaulis a pygmy sundew? Evidence of a long-distance dispersal between Western Australia and northern South America. Annals of Botany 110: 11-21.

Rivadavia F., Gonella P.M., Sano P.T., and Fleischmann, A. 2014. Elucidating the controversial Drosera montana complex (Droseraceae): a taxonomic revision. Phytotaxa 172: 141-175.

Schlauer, J. 1996. A dichotomous key to the genus Drosera L. (Droseraceae). Carnivorous Plant Newsletter 25: 67-88.

Seine, R., and Barthlott, W. 1993. On the morphology of trichomes and tentacles of Droseraceae Salisb. Beiträge zur Biologie der Pflanzen 67: 345-366.

Seine, R., and Barthlott, W. 1994. Some proposals on the infrageneric classification of Drosera L. Taxon 43: 583-589.

Takahashi, H., and Sohma, K. 1982. Pollen morphology of the Droseraceae and its related taxa. Sci. Rep. Tohoku Univ. 4 ser Biol. 38: 81-156. 


\section{CARNIVOROUS PLANT NEWSLETTER}

Journal of the International Carnivorous Plant Society

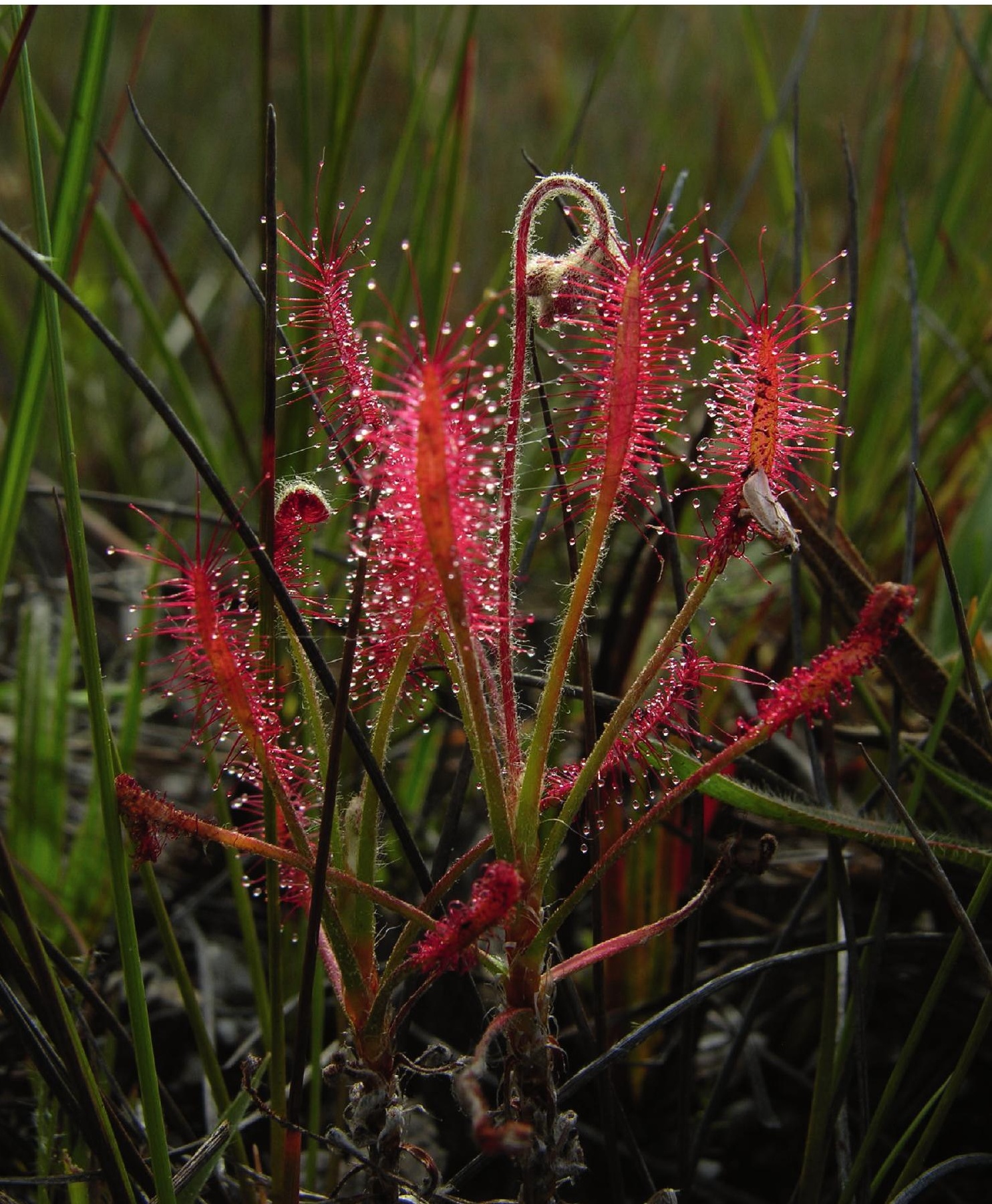




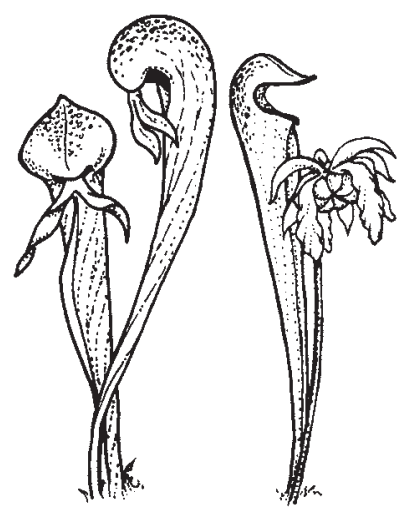

\title{
CARNIVOROUS \\ PLANT \\ NEWSLETTER
}

Journal of the International

Carnivorous Plant Society

www.carnivorousplants.org

\section{Volume 47, Number 1 March 2018}

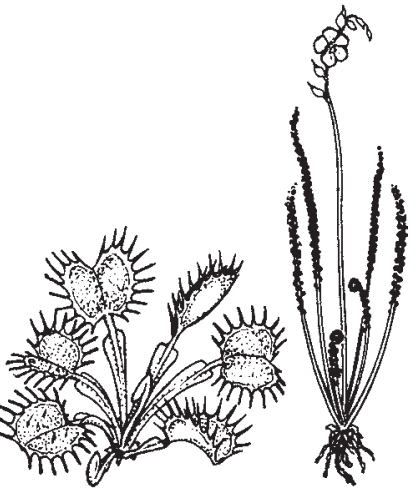

\section{Front Cover: Drosera chrysolepis, member of Drosera section Brasiliae, growing in the Serra do Cipó, Minas Gerais state, Brazil. Photo by Andreas Fleischmann. Article on page 4.}

\section{Back Cover: Paul Young standing next to his huge Sarracenia 'Leviathan'. Photo by Steve Sullivan. Article on page 36.}

Carnivorous Plant Newsletter is dedicated to spreading knowledge and news related to carnivorous plants. Reader contributions are essential for this mission to be successful. Do not hesitate to contact the editors with information about your plants, conservation projects, field trips, or noteworthy events. Advertisers should contact the editors. Views expressed in this publication are those of the authors, not the editorial staff.

All correspondence regarding dues, address changes and missing issues should be sent to the Membership Coordinator at the ICPS. Do not send such correspondence to the editors. Checks for subscriptions should be made to the International Carnivorous Plant Society in US funds. Dues, including a subscription, are \$30 per year.

\author{
International Carnivorous Plant Society, Inc. \\ 2121 N. California Blvd., Suite 290 \\ Walnut Creek, CA 94596-7351, USA \\ icps@carnivorousplants.org
}

$\begin{array}{ll}\text { President } & \text { Marcel van den Broek, marcel@carnivorousplants.org } \\ \text { Vice President } & \text { Richard Nunn, richardnunn@carnivorousplants.org } \\ \text { Secretary } & \text { Keith Becker, keith@carnivorousplants.org } \\ \text { Treasurer } & \text { Ryan Ward, ryan@carnivorousplants.org } \\ \text { Board Member } & \text { Alex Eilts, Conservation Director, alex@carnivorousplants.org } \\ \text { Board Member } & \text { Jan Schlauer, Cultivar Registrar, jan@carnivorousplants.org } \\ \text { Board Member } & \text { Bob Ziemer, bob@carnivorousplants.org } \\ \text { Membership Coordinator } & \text { Carolyn Becker, carolyn@carnivorousplants.org } \\ \text { Webmaster } & \text { John Brittnacher, john@carnivorousplants.org } \\ \text { Media Coordinator } & \text { Chad Williams, chad@carnivorousplants.org } \\ \text { Seed Bank Manager } & \text { Joe Griffin, joe@carnivorousplants.org } \\ \text { CPN Editors } & \text { editor@carnivorousplants.org } \\ \text { Managing Editor } & \text { Bob Ziemer } \\ \text { Editor } & \text { Barry Rice } \\ \text { Editor } & \text { Karl Herold } \\ \text { Editor } & \text { John Brittnacher } \\ \text { Science Editor } & \text { Fernando Rivadavia } \\ \text { Science Editor } & \text { Jan Schlauer }\end{array}$

Date of effective publication of the December 2017 issue of Carnivorous Plant Newsletter: 16 November 2017.

The ICPS is the International Cultivar Registration Authority (ICRA) for the names of cultivated carnivorous plants according to the International Code of Nomenclature for Cultivated Plants. Send relevant correspondence to the ICPS, Inc.

Carnivorous Plant Newsletter is published quarterly in March, June, September, and December by the ICPS, Inc., 2121 N. California Blvd., Suite 290, Walnut Creek, CA 94596, USA. Periodicals postage paid at Walnut Creek, CA and additional mailing offices. Postmaster: Send address changes to ICPS, Inc., 2121 N. California Blvd., Suite 290, Walnut Creek, CA 94596, USA. Printed by Allen Press, Inc., 810 E. 10th Street, Lawrence, KS 66044. Logo and masthead art: Paul Milauskas. (C) 2018 International Carnivorous Plant Society. All rights reserved. ISSN \#0190-9215 